\title{
EFFECT OF DIFFERENT TYPES OF IRRIGATION SYSTEMS ON SOYBEAN PRODUCTION UNDER CLAYEY SOIL CONDITIONS
}

\section{A. M. Okasha. ${ }^{1}$, W. F. EL Metwally ${ }^{2}$ and T.M. Attaffey ${ }^{2}$}

\begin{abstract}
Water is considered one of the most critical input resources for sustainable development at crop production. Selecting suitable irrigation system is very important to get high crop production and overcome water shortage. A field experiment was carried out at Rice Mechanization Center (RMC), Meet El-Deepa, and Kafer El-Sheikh Governorate during summer season 2014/2015 for soybean. The main aim of this research is to study the effect of different drip irrigation treatments on the
\end{abstract} productivity of soybean crop and irrigation water use efficiency (IWUE) under clayey soil conditions. The field treatments were designed as a split plots experimental design. The main plots were operating pressure head levels of 6(P1), 5(P2), 4(P3), and 3 meter (P4).Sub-main plots were included continuous drip irrigation (C), two levels of pulse drip irrigation in 15 min on/15 min off (S1) and 20 min on/20min off (S2) with three replication. Furrow irrigation (Tf) was used as control treatment soybean productivity, irrigation water use efficiency IWUE, uniformity parameters, and some plant characteristics were conducted to evaluate the performance of irrigation system and operating pressures. The important results indicated that:

- Pulsed drip irrigation achieved a good water distribution in clayey soil.

- Soybean productivity was increased by the percentage of 24.9, 23.7, 19.3, 14.0, 1.2\% comparing with (Tf) for P1S1, P1S2, P1C, P2S1, $P 2 S 2$, respectively. Wherever, it was decreased by the percentage of 2.8, 3.6, 21.1, 26.5, 37.5, 47.7\% comparing with Tf for P2C, P3S1, P3S2, P3C, P4S1, P4S2, P4C, respectively.

- The results showed that the highest values of IWUE and distribution uniformity were $0.54 \mathrm{~kg} / \mathrm{m3}$ at P1S1 treatment and $96.61 \%$ at $6 \mathrm{~m}$ pressure operating head $(P 1)$.

\footnotetext{
${ }^{1}$ Asst. Prof. Agric. Eng. Dept., Faculty of Agric, Kafrelsheikh University, Egypt.

${ }^{2}$ Researcher, Agric. Eng. Res. Inst., Agric. Res. Center, Egypt.
} 
- Application of pulsed drip irrigation was more effective to improve the front wetting zone of clay soil.

- In conclusion, pulse drip irrigation treatment of (15 min open/15 min close) and operating pressure head of $6 m$ gave the best results.

\section{INTRODUCTION}

I is necessary to use modern techniques to promote productivity per unit area by using modern irrigation systems, which the important technologies that help to improve the productivity in addition to reducing the amount of water added to the crop. Study of engineering factors affecting on modern irrigation systems such as pulsed surface drip irrigation and its impact on the productivity of crop soybean and irrigation water use efficiency are the most important problems faced by the ongoing this search. Karmeli and Peri (1974) suggested that pulse irrigation is an irrigation technique achieving a relatively low application rate while using an irrigation device with a higher application rate. Complete pulse irrigation is composed of a series of irrigation time cycles where each cycle includes two phases: the operating phase followed by the resting or non-operative phase. Mostaghimi and Mitchell (1983) conducted laboratory experiments to study effects of trickle emitter discharge rate on the distribution of soil moisture in a silty-clay loam soil. The results indicated that on/off trickling wets a greater volume of soil with the same amount of applied water. Thus, reduction in the downward movement of soil moisture under pulsed applications would cause less deep drainage below the root zone. Pitts et al.(1991)found that the two drip irrigation frequencies (three times per day, one time per day) had not affected tomato yield. However, root length density was significantly affected by irrigation treatment at the 0 to $0.15 \mathrm{~m}$ depth with the more frequent irrigation treatment. Kang (2000) evaluated the effect of operating pressure heads on water application uniformity in micro irrigation sub main unit. Results showed that water application uniformity either increases or slightly decreases as operating pressure head increases in a range when the emission exponent $x \leq 0.5$ in most cases. The water application uniformity decreases as operating pressure head increases in a range when the emission exponent $x>0.5$. 
Wang et al. (2000) found that soil water contents were higher directly under the drip tapes in drip irrigation, but were relatively more uniform across the whole soil surface in sprinkler irrigation. Zin El-Abedin (2006) showed that pulse drip irrigation is a recent concept where small frequent irrigation applications are applied to saturate the soil and meet the plant water requirements. Elmaloglou and Malamos (2006) estimated the vertical and surface water movement under a trickle source. Account evaporation and water extraction of the plant root system, which require complicated procedures such as numerical solution of the soil moisture flow equation. Elmaloglou and Diamantopoulos (2007) found that the vertical component of the wetting front was greater for the pulse than for the continuous irrigation for a time equal to irrigation duration. However, this difference was practically eliminated for a longer time. Saied et al. (2008) indicated that irrigation by using surface drip tended to increase the seed yield of soybean by $18.84 \%, 37.68 \%, 17.39 \%$, $11.59 \%$ and $4.35 \%$, compared to semiportable, gun, minisprinkler, floppy, and subsurface drip irrigation system, respectively in old lands at Sakha agricultural station farm, Kafr El-Sheikh Governorate. Malek and Peters (2010) presented two empirical relationships that calculate the width and depth of the wetted zone. They developed their empirical models by regression analysis. In their relationship, it was assumed that the radius and depth of the wetted zone related to the total volume of water, discharge rate, hydraulic conductivity, and the average soil water content during irrigation. Skaggs et al. (2010) used a numerical simulations and field trials to investigate the effects of application rate, pulsed water application, and antecedent water content on the spreading of water from drip emitters. Simulation results showed that pulsing and lower application rates produced minor increases in horizontal spreading at the end of water application. The small increases were primarily due to longer irrigation times, however, and not to flow phenomena associated with pulsing or low application rates. Liu, et al. (2011) reported that Micro-irrigation technology is applied worldwide for its advantages of water saving, energy saving, high productivity, high efficiency and strong adaptability to soil and landform. Some developed countries with a shortage of water resources have turned the priority of developing 
water-efficient irrigation technology to micro irrigation, especially for drip irrigation, since the 1970s. Eid et al. (2013) found that pulse drip irrigation and mulching systems tended to increase and improving the yield of soybean. Applying the irrigation requirements on 8 pulses/day with using black plastic mulch (BPM) was the best conditions because under these conditions was occurred the highest value of yield, quality traits, and irrigation water use efficiency (IWUE) soybean. There was a significant difference between this case and treatments of adding of daily water requirements on 4 times, 12 times and daily on one time with mulching system of rice straw mulch "RSM" and the control treatment was soil surface without mulch "WM". Singh et al. (2014) evaluated various methods of estimating evapotranspiration to predict water requirement of soybean and wheat crops. The water requirement of soybean and wheat estimated by Penmann-Monteith method was in close agreement $(-2.58 \%$ and $9.26 \%$ deviation) with the measured average water requirement (401.6 and $352.2 \mathrm{~mm}$ ) respectively followed by Hargreaves method for Bhopal district.

Therefore, the present investigation was to study the effect of furrow irrigation, continuous drip irrigation and pulsed drip irrigation on soybean production under clayey soil and maximization of irrigation water use efficiency.

\section{MATERIAL AND METHODS}

\subsection{Location and soil of experimental field}

The experimental field was carried out at Rice Mechanization Center (RMC), Meet El-Deepa, Kafr El-Sheikh Governorate, Egypt situated at $31^{\circ} 6^{\prime} \mathrm{N}$ latitude, $30^{\circ} 50^{\prime} \mathrm{E}$ longitude, and an elevation of about 6 meters above mean sea level during summer growing season 2014/2015 to select a suitable irrigation parameters for producing soybean crop of Giza111 variety. The average values of particle size distribution, bulk density, field capacity (F.C), permanent wilting point (P.W.P) and saturation hydraulic conductivity $\left(\mathrm{k}_{\mathrm{s}}\right)$ for the experimental soil are presented in Table(1). Soil infiltration was measured by using double-ring infiltrometer. Saturation hydraulic conductivity was considered as final infiltration rate. 
Table 1: Soil physical analysis of experimental site

\begin{tabular}{|c|c|c|c|c|c|c|c|c|}
\hline \multirow{2}{*}{$\begin{array}{l}\text { Soil } \\
\text { depth, } \\
\mathrm{cm}\end{array}$} & \multicolumn{3}{|c|}{ Particle size distribution } & \multirow{2}{*}{$\begin{array}{l}\text { Soil } \\
\text { texture }\end{array}$} & \multirow{2}{*}{$\begin{array}{c}\text { Field } \\
\text { capacity, } \\
\%\end{array}$} & \multirow{2}{*}{$\begin{array}{c}\text { Permanent } \\
\text { wilting } \\
\text { point, \% }\end{array}$} & \multirow{2}{*}{$\begin{array}{c}\text { Bulk } \\
\text { density } \\
, \mathrm{g} / \mathrm{cm}^{3}\end{array}$} & \multirow{2}{*}{$\begin{array}{c}\text { Saturation } \\
\text { hydraulic } \\
\text { conductivity, } \\
\mathrm{cm} / \mathrm{h} \\
\end{array}$} \\
\hline & $\begin{array}{c}\text { Sand, } \\
\%\end{array}$ & $\begin{array}{l}\text { Silt, } \\
\%\end{array}$ & $\begin{array}{c}\text { Clay, } \\
\%\end{array}$ & & & & & \\
\hline $0-15$ & 10.42 & 31.25 & 58.33 & Clay & 44.80 & 21.36 & 1.10 & \multirow{4}{*}{2.59} \\
\hline $15-30$ & 13.00 & 32.00 & 55.00 & Clay & 41.45 & 21.40 & 1.22 & \\
\hline $30-45$ & 12.00 & 29.00 & 59.00 & Clay & 39.00 & 21.00 & 1.28 & \\
\hline $45-60$ & 12.00 & 28.00 & 60.00 & Clay & 37.40 & 20.85 & 1.31 & \\
\hline
\end{tabular}

\subsection{System installation and experimental treatments}

Irrigation system components consisted of pump with $30 \mathrm{~m}^{3} / \mathrm{h}$ discharge, $23 \mathrm{~m}$ vertical head and it was driven by a gasoline engine has power of $3.7 \mathrm{~kW}$. Screen filter and back flow prevention device, pressure regulator, pressure gauges, and flow-meter and control valves. The main line made from solid PE pipes with $75 \mathrm{~mm}$ outer diameter (OD) to convey the water from the source to the main control points in the field. Sub-main lines made from PE pipes with $50 \mathrm{~mm}$ outer diameter (OD) was connected to lateral drip tapes of PE with $16 \mathrm{~mm}$ inner diameter (ID) and $46 \mathrm{~m}$ in long, $10 \mathrm{~cm}$ spacing between emitters and $1350 \ell \mathrm{ph} / 100 \mathrm{~m}$ discharge. Seeds of soybean variety of Giza111 were planted on $1^{\text {st }}$ of June by the manual method at $3-5 \mathrm{~cm}$ soil depth, $64 \mathrm{~cm}$ row spacing and $5-7 \mathrm{~cm}$ on the rows in a soil. It was harvested on $3^{\text {rd }}$ of October by handily methods. The field treatments were designed as a split plots experimental design. Main plot was concluded continuous drip irrigation (C), pulse drip irrigation $15 \mathrm{~min}$, on/15 $\mathrm{min}$ off (S1) and pulse drip irrigation 20 min on/20min off (S2). The cycle time of pulsed application, defined as the time between the beginning of one pulse and the beginning of the next, was 0.5 hour (i.e., 0.25 hour on and 0.25 hour off pulses). The cycle ratio, defined as the ratio of on time to cycle time, was one half. Furrow irrigation (Tf) was used as control treatment with three replications. Submain plots were operating pressure head levels were used 6(P1), 5(P2), 4(P3), and $3 \mathrm{~m}$ (P4). The experimental design are shown in Figure 1. Routine operations for crop service were carried out on time, e.g. control of pests and diseases, fertilization and weeding according to recommendations. 


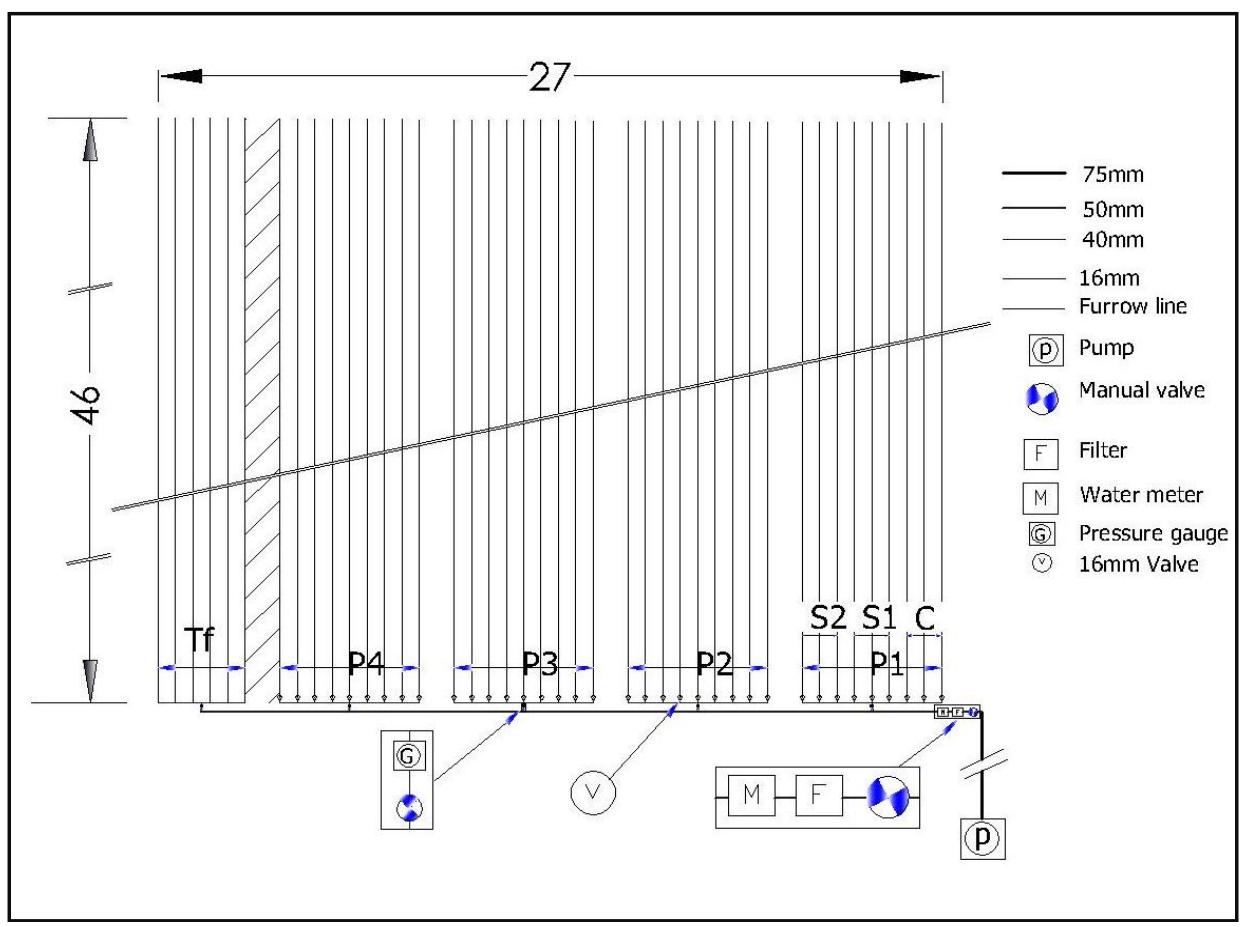

Figure 1: Layout of irrigation systems with the experimental design

\subsection{Estimation of water requirements and irrigation application}

Water requirements were computed for irrigating soybean crop based on CROPWAT 8 program (Allen, et al. 1998) as shown in Table 2 and Table 3 for furrow irrigation and drip irrigation, respectively. Field efficiencies were used $70 \%$ and $85 \%$ for furrow and drip irrigation, respectively. (Irmak et al. 2011).

Table 2: Total irrigation water requirements for furrow irrigation/season

\begin{tabular}{|c|c|c|c|c|c|}
\hline \multirow{2}{*}{$\begin{array}{l}\text { Date of } \\
\text { season }\end{array}$} & \multirow{2}{*}{$\begin{array}{c}\text { Day } \\
\text { from } \\
\text { planting }\end{array}$} & \multirow[t]{2}{*}{ Plant stage } & \multicolumn{2}{|c|}{$\begin{array}{l}\text { Actual irrigation } \\
\text { requirements }\end{array}$} & \multirow[t]{2}{*}{ Notes } \\
\hline & & & $\mathrm{mm}$ & $\mathrm{m}^{3} / \mathrm{fed}$ & \\
\hline 01-Jun & 1 & Initial & 50.9 & \multirow{2}{*}{584.22} & \multirow{2}{*}{$\begin{array}{c}\text { Applied water before } \\
\text { planting and first } \\
\text { irrigation }\end{array}$} \\
\hline 16-Jun & 16 & Initial & 88.2 & & \\
\hline 06-Jul & 36 & Developmental & 163.2 & 685.44 & \multirow{6}{*}{$\begin{array}{l}\text { Irrigation interval } \\
\text { was } 9-12 \text { days }\end{array}$} \\
\hline 26-Jul & 56 & Middle & 186 & 705.6 & \\
\hline 16-Aug & 77 & Middle & 184.6 & 775.32 & \\
\hline 08-Sep & 100 & Middle & 183.6 & 771.12 & \\
\hline 03-Oct & End & End & & & \\
\hline Summation & 125 & & 856.5 & 3597.3 & \\
\hline
\end{tabular}


Table 3: Total irrigation water requirements for drip irrigation/season

\begin{tabular}{|c|c|c|c|c|c|}
\hline \multirow[t]{2}{*}{$\begin{array}{l}\text { Date of } \\
\text { season }\end{array}$} & \multirow[t]{2}{*}{$\begin{array}{l}\text { Day from } \\
\text { planting }\end{array}$} & \multirow[t]{2}{*}{ Stage } & \multicolumn{2}{|c|}{$\begin{array}{c}\text { Actual irrigation } \\
\text { requirements }\end{array}$} & \multirow[t]{2}{*}{ Notes } \\
\hline & & & $\mathrm{mm}$ & $\mathrm{m}^{3} /$ fed. & \\
\hline 01-Jun & 1 & Initial & 50.9 & \multirow[b]{2}{*}{584.22} & \multirow{2}{*}{$\begin{array}{c}\text { Applied water } \\
\text { before planting } \\
\text { and first irrigation }\end{array}$} \\
\hline 16-Jun & 16 & Initial & 88.2 & & \\
\hline 06-Jul & 36 & Developmental & 134.4 & 564.48 & \multirow{6}{*}{$\begin{array}{c}\text { Water was applied } \\
\text { once in every } \\
\text { three days }\end{array}$} \\
\hline 26-Jul & 56 & Middle & 153.2 & 581.08 & \\
\hline 16-Aug & 77 & Middle & 152.0 & 638.49 & \\
\hline 08-Sep & 100 & Middle & 152.2 & 635.04 & \\
\hline 03-Oct & End & End & & & \\
\hline Summation & 125 & & 706.3 & 3003.31 & \\
\hline
\end{tabular}

\subsection{Determination of flow rate- pressure relationship}

The values of emitters' flow rates with operating pressure under experimental field were described by the power curve equation as presented by (Keller and Karmeli 1975) as follow:

$$
q=k(h)^{x}
$$

Where:

$q=$ the emitter flow rate, $\ell / \mathrm{h}$,

$k=$ constant of proportionality that characterizes each emitter,

$h=$ operating pressure head, $\mathrm{m}$ and

$x=$ emitter discharge exponent that is characterized by the flow regime. The flow rate-pressure for drip line $(10$ emitters $/ \mathrm{m})$ was shown in

Table 4.

Table 4: Emitter flow rate under different pressure heads

\begin{tabular}{|c|c|c|}
\hline Operating pressure head, $\mathrm{m}$ & Emitter flow rates, $\ell / \mathrm{h}$ & $\begin{array}{c}\text { Flow rate- pressure } \\
\text { relationship }\end{array}$ \\
\hline 6 & 1.377 & \multirow{2}{*}{$q=0.525(h)^{0.53}$} \\
\hline 5 & 1.229 & \\
\hline 4 & 1.059 & \\
\hline 3 & 0.958 & \\
\hline
\end{tabular}




\subsection{Determination of uniformity of drip line systems}

These measurements were used to determine emission uniformity and application efficiency. For each testing, 30 emitters were selected from head, middle and tail ends of drip tape, randomly. Water was collected from one meter of outflow (10 emitters) in metal tape with dimensions of $100 \mathrm{~cm}$ length, $10 \mathrm{~cm}$ width and $3 \mathrm{~cm}$ depth for known time duration.

\section{The coefficients of manufacturer's variation:}

The coefficients of manufacturer's variation describe the quality of the processes which used to manufacture those emission devices. It was computed with the following equation. (Cited from, James 1988)

$$
\mathrm{cv}=\frac{\left(\mathrm{q}_{1+}^{2} \mathrm{q}_{2}^{2}+\cdots+\mathrm{q}_{\mathrm{n}-\mathrm{n}}^{2} \overline{\mathrm{q}}^{2}\right)^{0.5}}{\overline{\mathrm{q}}(\mathrm{n}-1)^{0.5}}
$$

Where:

$\mathrm{CV}=$ manufacturer's coefficient of variation,

$\mathrm{q}_{1}, \mathrm{q}_{2} \ldots \ldots . \mathrm{q}_{\mathrm{n}}=$ discharge of emission devices $(\ell / \mathrm{h})$

$\bar{q}=$ average discharge of emission devices tested $(\ell / \mathrm{h})$ and

$\mathrm{n}=$ number of emission devices tested.

Emission uniformity: Emission uniformity has been developed for evaluating trickle lateral design and emission device selection and is defined by the following equation. (karmeli and keller, 1975):

$$
E U=\left(100\left(1.0-\frac{1.27}{\sqrt{N_{e}}} C V\right) \frac{Q_{\text {min }}}{Q_{\text {ave }}}\right.
$$

Where:

$E U=$ the design emission uniformity in percent,

$\mathrm{N}_{\mathrm{e}}=$ number of point source emitters per emission point,

$\mathrm{CV}=$ manufacturer's coefficient of variation,

$\mathrm{Q}_{\min }=$ the minimum emitter discharge rate in the system $(\ell / \mathrm{h})$, and

$\mathrm{Q}_{\mathrm{ave}}=$ the average or design emitter discharge rate, $\ell / \mathrm{h}$.

Christiansen uniformity coefficient: The uniformity of application is evaluated using the Christiansen uniformity coefficient according to the following equation (Christiansen, 1941; ASAE, 2001)

$$
C U=\left[1-\frac{\sum_{i=1}^{i=n}\left|q_{i}-\bar{q}\right|}{\bar{q} \times n}\right] \times 100
$$


Where:

$\mathrm{CU}=$ Christiansen uniformity coefficient,

$\mathrm{n}=$ number of observed emitter or cans,

$\mathrm{q}_{\mathrm{i}}=$ emitter flow rate, $\ell / \mathrm{h}$, and

$\bar{q}=$ average discharge of emission devices tested $(\ell / \mathrm{h})$

Distribution uniformity: Distribution uniformity is expressed as a decimal as suggested by Burt et al. (1997).

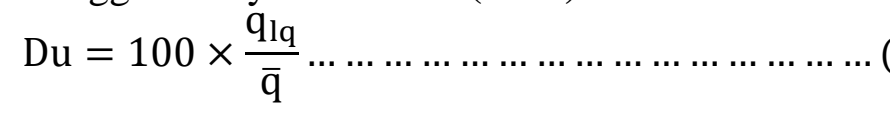

Where:

$\mathrm{Du}=$ Distribution uniformity, \%

$\mathrm{q}_{\mathrm{lq}}=$ low-quarter average volume amount caught, and

$\bar{q}=$ average amount volume caught.

\subsection{Estimation of irrigation duration, horizontal and vertical wetting} zone

Irrigation water requirement (IWR) per day were used to determine irrigation duration. For example, IWR to day of 21/7/2015 was $5.715 \mathrm{~mm}$ equal $0.168 \mathrm{~m}^{3}$ per treatment. Horizontal and the vertical wetting zone was measured by tape and operating duration of the emitter by a stop watch. Predicted soil moisture distribution was investigated by empirical model of Schwartzman and Zur (1986) is expressed as:

$$
\begin{aligned}
& \mathrm{Z}=2.54\left(\mathrm{~V}_{\mathrm{w}}\right)^{0.63}\left(\mathrm{~K}_{\mathrm{s}} \mathrm{Q}^{-1}\right)^{0.45} \ldots \\
& \mathrm{W}=1.82\left(\mathrm{~V}_{\mathrm{w}}\right)^{0.22}\left(\mathrm{~K}_{\mathrm{s}} \mathrm{Q}^{-1}\right)^{-0.17}
\end{aligned}
$$

Where $\mathrm{W}$ and $\mathrm{Z}$ are horizontal and vertical dimensions of the wetting profile in meters, respectively, $\mathrm{V}_{\mathrm{w}}$ is the total volume of applied water $\left(\mathrm{m}^{3}\right), \mathrm{Q}$ is the emitter discharge $\left(\mathrm{m}^{3} \mathrm{~s}^{-1}\right)$, and $\mathrm{K}_{\mathrm{s}}$ is the soil saturated hydraulic conductivity $\left(\mathrm{ms}^{-1}\right)$

2.7 Soybean Crop characteristics and irrigation water use efficiency (IWUE)

At the end of growing season, crop parameters were determined by cutting of 10 plants from every treatment. Height, number of pods, the weight of 100 seeds and yield of soybean crop at an average moisture content of $15 \%$ wet basis was measured. Irrigation water use efficiency of Soybean crop was calculated according to (Ali, 2010) as follows: 


$$
\text { IWUE }=\frac{\text { Total yield, }(\mathrm{kg} / \mathrm{fed} *)}{\text { Total applied irrigation water, }\left(\mathrm{m}^{3} / \mathrm{fed}\right)}
$$

Where:

IWUE $=$ Irrigation water use efficiency, $\mathrm{kg} / \mathrm{m}^{3}$

$*$ fed $=4200 \mathrm{~m}^{2}$

\section{RESULTS AND DISCUSSION}

\subsection{Uniformity of drip line}

Table 5 shows the effect of operating pressure head on coefficients of manufacturer's variation (C.V), emission uniformity (EU), Christiansen uniformity coefficient (CU), and distribution uniformity (DU). The low $\mathrm{CV}$ indicated good performance of the drip line system according to ASAE (2001) (cited from James 1988). According to Pitts (1997) Du greater than $87 \%$ implied an excellent functioning of the drip system. The present data indicates that, distribution uniformity (DU) increased by increasing operating pressure head. The highest value of DU was $96.61 \%$ that obtained at $6 \mathrm{~m}$ operating pressure head, while the lowest value was $85.34 \%$ at $4 \mathrm{~m}$ operating pressure head. The highest value of distribution uniformity mains a good water distributed to different areas in the field. Emission uniformity (EU). The highest values of emission uniformity were 90.88 and $91.83 \%$ at 6 and $5 \mathrm{~m}$ operating pressure head, respectively. Also, data in Table 5 indicated that increasing manufacturer's variation tended to decrease values of emission uniformity, uniformity coefficient and distribution uniformity. Maximum and minimum values of CU were 97.54 and $91.79 \%$ achieved at 5 and $4 \mathrm{~m}$, respectively.

Table 5: Effect of operating pressure heads on CV, EU, CU and DU

\begin{tabular}{|c|c|c|c|c|}
\hline \multirow{2}{*}{ Parameter } & \multicolumn{4}{|c|}{ Operating pressure heads, m } \\
\cline { 2 - 5 } & 3 & 4 & 5 & 6 \\
\hline CV & 0.116 & 0.146 & 0.037 & 0.047 \\
\hline EU, \% & 74.80 & 69.48 & 91.83 & 90.88 \\
\hline CU,\% & 91.79 & 90.22 & 97.54 & 96.45 \\
\hline DU, \% & 87.68 & 85.34 & 96.31 & 96.61 \\
\hline
\end{tabular}




\subsection{Irrigation duration, horizontal and the vertical wetting zone}

The effect of operating pressure head and irrigation type on flow rate as listed in Table 6. The present data indicated that, flow rate and discharge decreased by decreasing operating pressure head at the same of irrigation water requirements. The maximum and minimum values of flow rate were 1.377 and $0.959 \mathrm{l} / \mathrm{h}$ per emitter at 6 and $3 \mathrm{~m}$ operating pressure heads, respectively. Irrigation duration increased by decreeing of operating pressure head. Also, it increased by increasing of pulse duration. The minimum of irrigation duration was 0.795 at operating pressure head of $6 \mathrm{~m}$ and continuous drip irrigation. The maximum value of irrigation duration was $2.15 \mathrm{~h}$ at 3 operating pressure head and pulsed drip irrigation either $15 \mathrm{~min}$ on/15 $\mathrm{min}$ off (S1) or $20 \mathrm{~min}$ on/20min off (S2). Figures 2 and 3 showed the effect of operating pressure head and drip irrigation type on wetted soil width (W) and wetted soil width (Z). Wetted soil width increased by increasing operating pressure head. By applied pulsed drip irrigation achieved low values of wetted soil width compared with continuous drip irrigation (C). The maximum value of wetted soil width (W) was $0.247 \mathrm{~m}$ at 6 operating pressure head $15 \mathrm{~min}$ on/15 min off (S1) while, the minimum value of it was $0.204 \mathrm{~m}$ at 3 operating pressure head and $20 \mathrm{~min}$ on/20 $\mathrm{min}$ off (S2). Vis versa, wetted soil depth decreased by increasing operating pressure head. By applied pulsed drip irrigation achieved high values of wetted soil depth compared with continuous drip irrigation (C). Maximum value of wetted soil depth (Z) were 0.155 at $3 \mathrm{~m}$ operating pressure head and (S2). Minimum value of $(\mathrm{Z})$ was and $0.118 \mathrm{~m}$ at $6 \mathrm{~m}$ operating pressure heads and continuous drip irrigation. Results showed that wetted soil patterns as influenced by different flow rates or using different levels of operating pressure heads and drip irrigation types (C, S1 and S2) at the same amount of water application. Vertical component of the wetting front is deeper for the smaller than for the higher discharge rate. This agrees with Kang (2000) and Elmaloglou and Diamantopoulos (2007). While the horizontal component of wetting front is wider than for the higher discharge rate, in the duration of off cycle, wetted soil volume was vertically moved by gravitational effect, but it was insignificantly changed in horizontal directions. This agrees with Amer (2010). On other hand, increasing drip discharge rate resulted in a decrease in the horizontal component and an 
increase in the vertical component of the wetted soil profile. Also, pulse drip irrigation, allowed the water to follow through the drip line and inter the soil when time was on. While during the time is off the soil moisture was allowed to be redistributed and resulted in more uniform distribution pattern. This agreed with El-Abedin (2006). The correlation between the predicted and measured soil moisture distribution patterns was satisfactory as show in Figures $\mathbf{4}$ and $\mathbf{5}$.

Table 6: Effect of operating pressure heads and irrigation types on flow rate of emitter and irrigation duration for one irrigation at 21/7/2015

\begin{tabular}{|c|c|c|c|}
\hline $\begin{array}{l}\text { Operating } \\
\text { pressure } \\
\text { head, } m\end{array}$ & $\begin{array}{l}\text { Irrigation } \\
\text { types }\end{array}$ & $\begin{array}{l}\text { Emitter flow } \\
\text { rate, } \ell \mathrm{ph}\end{array}$ & $\begin{array}{l}\text { Irrigation } \\
\text { duration, } \mathrm{h}\end{array}$ \\
\hline \multirow{3}{*}{ 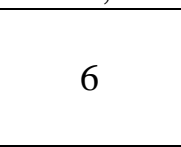 } & C & \multirow{3}{*}{1.377} & 0.795 \\
\hline & S1 & & 1.550 \\
\hline & S2 & & 1.467 \\
\hline \multirow{3}{*}{5} & $\mathrm{C}$ & \multirow{3}{*}{1.229} & 0.892 \\
\hline & S1 & & 1.650 \\
\hline & S2 & & 1.567 \\
\hline \multirow{3}{*}{4} & $\mathrm{C}$ & \multirow{3}{*}{1.095} & 1.035 \\
\hline & S1 & & 2.050 \\
\hline & S2 & & 2.050 \\
\hline \multirow{3}{*}{3} & $\mathrm{C}$ & \multirow{3}{*}{0.959} & 1.143 \\
\hline & S1 & & 2.150 \\
\hline & S2 & & 2.150 \\
\hline
\end{tabular}

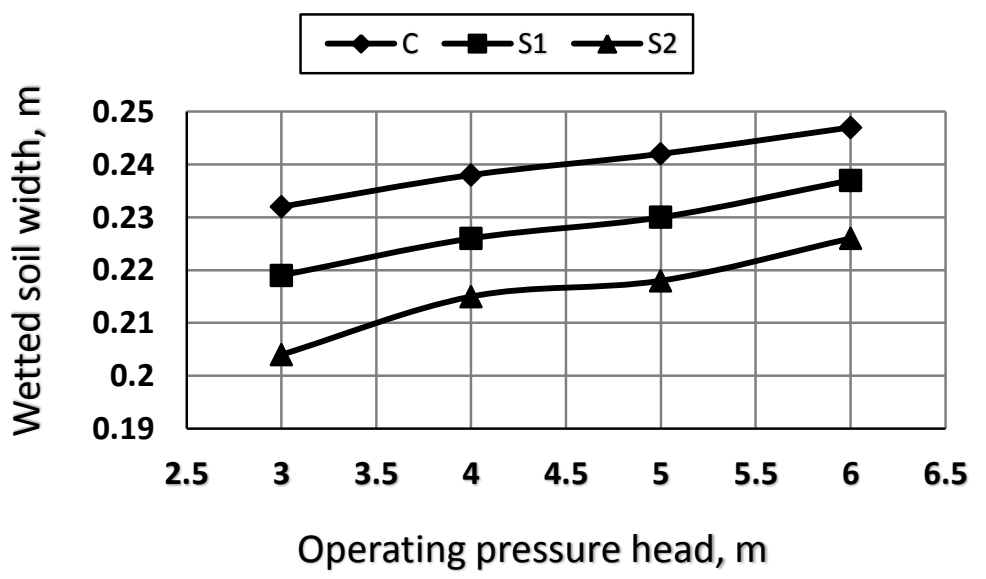

Figure 2: Effect of operating pressure head on horizontal wetting zone (wetted soil width). 


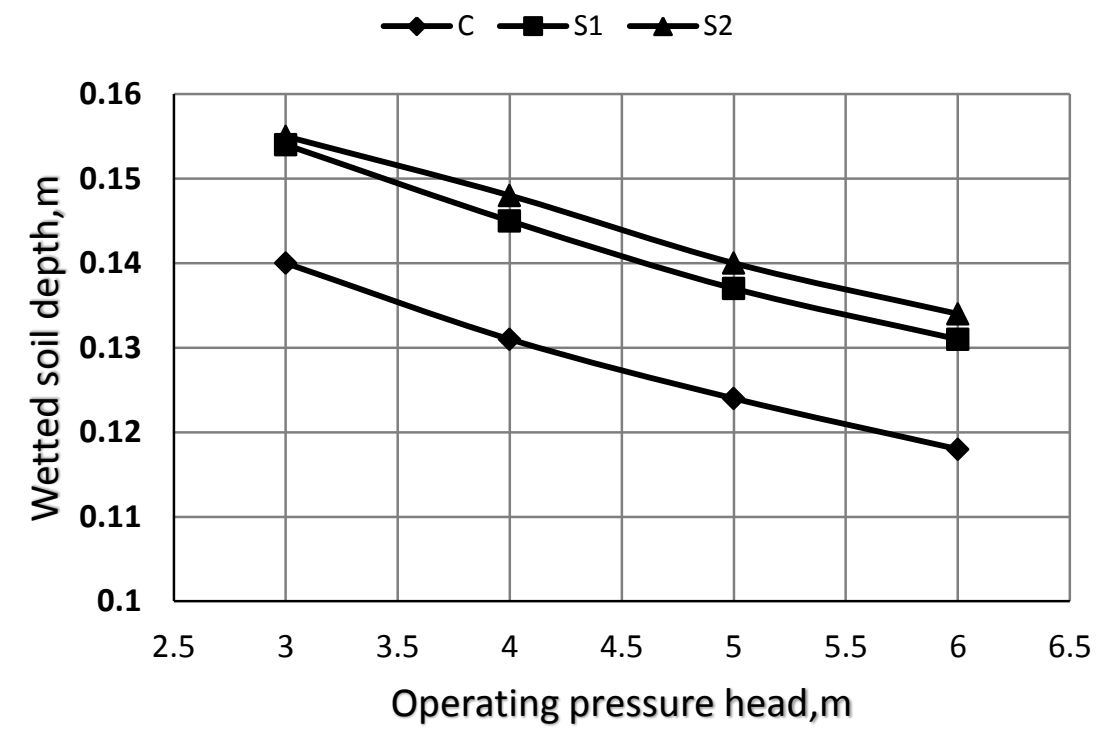

Figure 3: Effect of operating pressure head on vertical wetting zone (wetted soil depth).

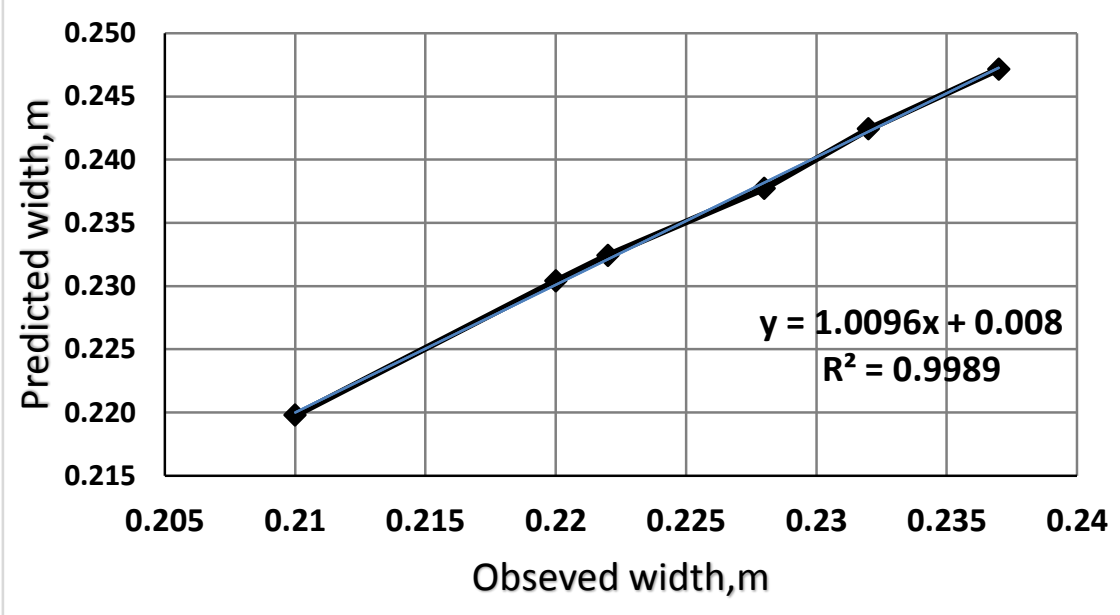

Figure 4: The relationship between observed and predicted wetting width. 


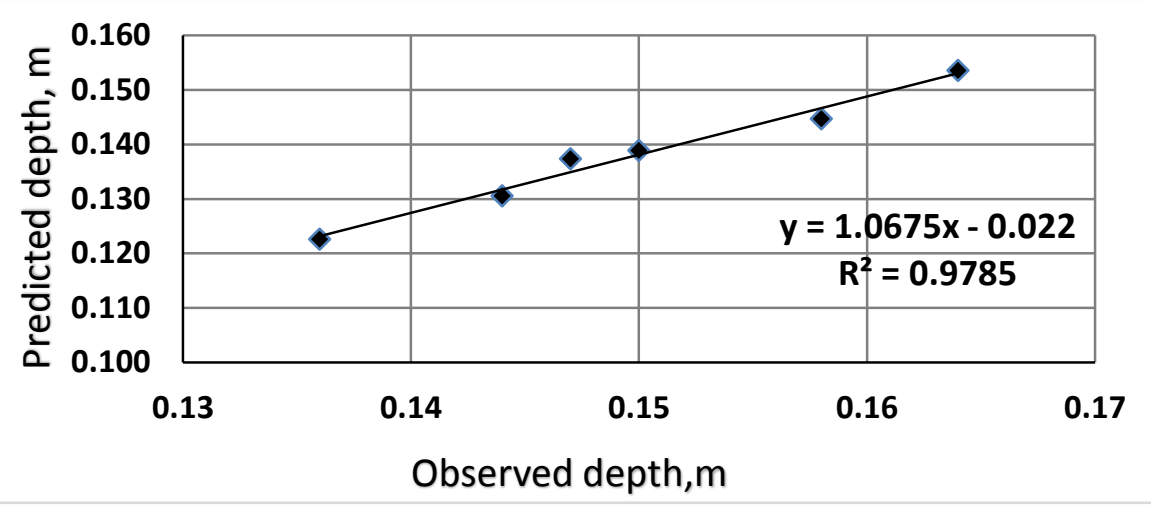

Figure 5: The relationship between observed and predicted wetting depth.

\subsection{Soybean characteristics, productivity and irrigation water use efficiency}

The effect of operating pressure head and irrigation system treatments on soybean crop characteristics, productivity and irrigation water use efficiency (IWUE) is presented in Table 6 and Figures 6 and 7. It cleared that, some of experimental treatments of soybean parameters there was significant and other not significant of average values. Based on the value differences, there no a finite direction because some grains were not completed and pods had three or two or one grain only. The maximum and minimum values of 100 grain weight was $15.91 \mathrm{~g}$ and $10.20 \mathrm{~g}$ at P1C and P2S2, respectively. Results showed that, soybean yield increased by increasing operating pressure head and pulsed drip irrigation. The highest value of yield was $1617.2 \mathrm{~kg} / \mathrm{fed}$ can be achieved by operating pressure of $6 \mathrm{~m}(\mathrm{P} 1)$ and pulsed drip irrigation treatment of (S1). The results indicated that, values of productivity trend to increase according to uniformity parameters and a good distribution of wetted soil under drip line. By comparison the values of yield between the control (Tf) and others treatments. It found that Soybean productivity was increased by percentage of 24.9, 23.7, 19.3, 14.0, 1.2\% comparing with (Tf) for P1S1, P1S2, P1C, P2S1, P2S2, respectively. Wherever, it was decreased by percentage of $2.8,3.6,21.1,26.5,37.5,47.7 \%$ comparing with Tf for P2C, P3S1, P3S2, P3C, P4S1, P4S2, P4C, respectively. Also, low operating pressure head do not prefer at the beginning of the season because the root depth of soybean is less. Irrigation water use efficiency 
(IWUE) increased by increasing operating pressure head and applying of pulse drip irrigation. The highest irrigation water use efficiency was 0.54 $\mathrm{kg} / \mathrm{m}^{3}$ at P1S1 treatment while, the lowest was $0.27 \mathrm{~kg} / \mathrm{m}^{3}$ at P4S2 treatment. Irrigation water use efficiencies varied according to productivity and water irrigation requirements.

Table 6: Effect of irrigation systems on soybean crop parameters and irrigation water use efficiency

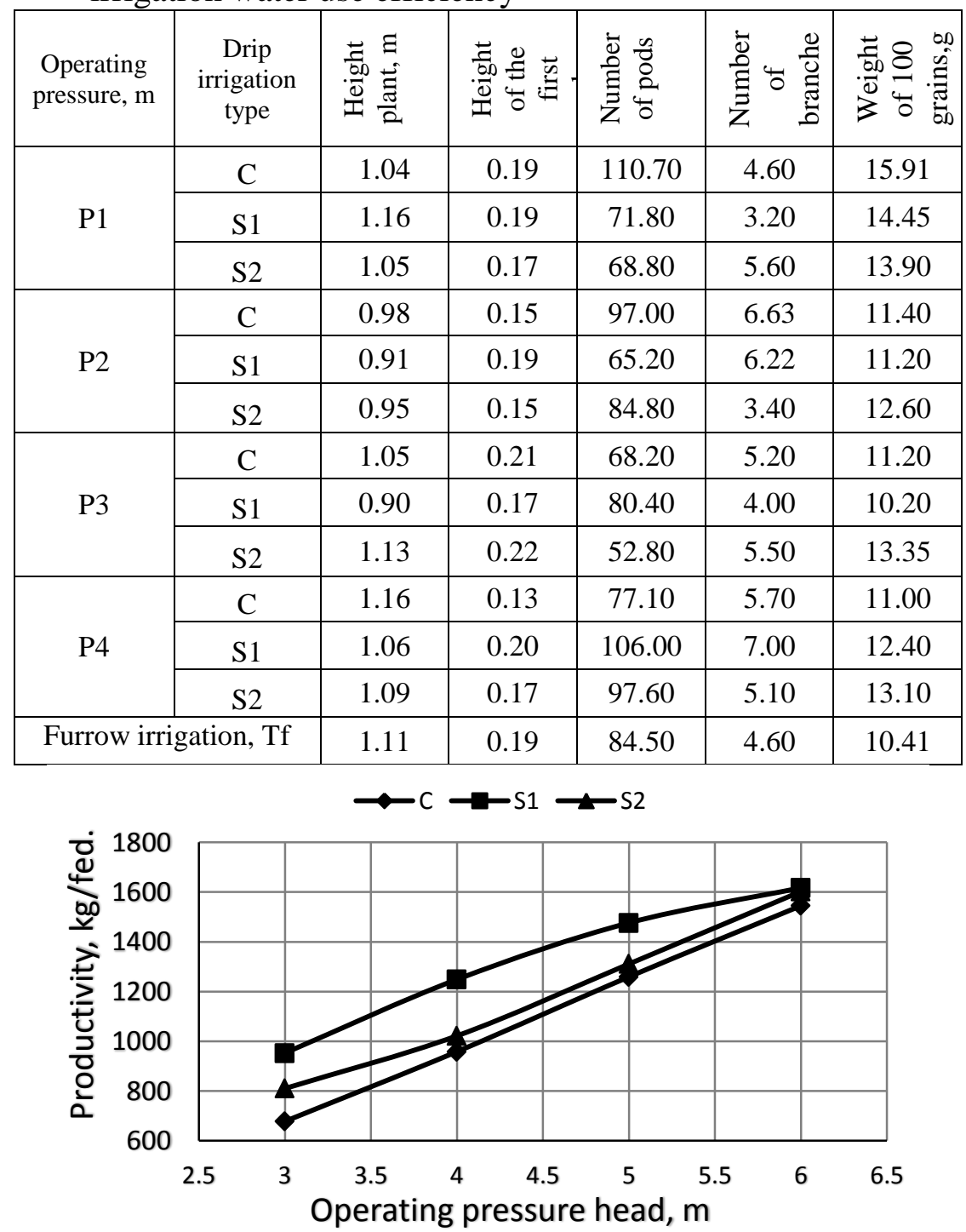

Figure 6: Effect of operating pressure head and irrigation types on soybean productivity 


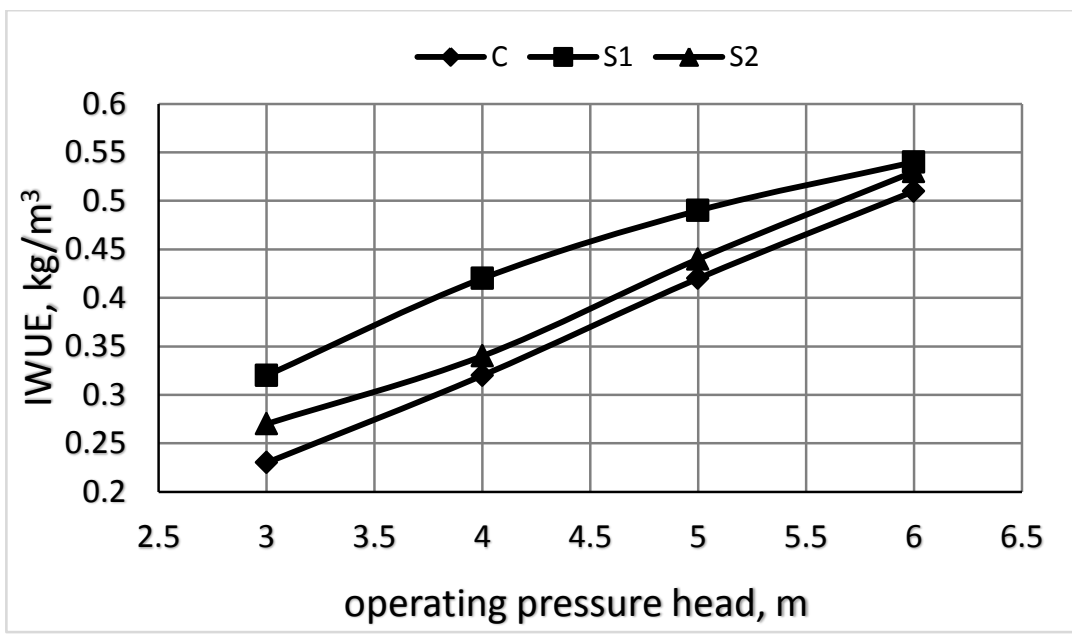

Figure 7: Effect of operating pressure head and irrigation types on irrigation water use efficiency

\section{CONCLUSIONS}

$>$ Pulsed drip irrigation can replace continuous small discharge rates to reduce irrigation water runoff problems on clayey soils.

$>$ Water distribution in soil is affected by operating pressure heads. The wetting width zone is large if the operating pressure head is large and vice versa it is small if the operating pressure head is small.

$>$ The correct application of engineering factors for the use of drip irrigation types (operating pressure head ranges of 5-6m and $15 / 15$ on-off pulsed drip) in the clayey soil achieves the highest uniformity parameters, productivity and irrigation water use efficiency of soybean.

\section{REFERANCES}

Ali, H. (2010). Fundamentals of irrigation and on-farm water management (Vol.1). Springer Science \& Business Media. Page, 525.

Allen, R. G.; L. S. Pereira; D. Raes and M. Smith (1998). Crop evapotranspiration-Guidelines for computing crop water 
requirements-FAO Irrigation and drainage paper 56. FAO, Rome, 300(9), D05109

Amer, H. A; A. Elsharkawi and A.S. Hassan (2010). Revising Wetted Soil Volume under Trickle Source for Irrigation Scheduling. Misr J. Agric.Eng., 27(4):1162-1183.

Arora,V.K.; C.B.Singh; A.S. Sidhu and S.S. Thind (2011) Irrigation, tillage and mulching effects on soybean wield and water productivity in relation to soil texture. Agricultural Water Management 98 (2011) 563-568.

ASAE. (2001). Test procedure for determining the uniformity of water distribution of center pivot and lateral move irrigation machines equipped with spray or sprinkler nozzles. ANSI/ASAE Standard S436.1, American Society of Agricultural Engineers, St. Joseph, MI.

Burt, C.; A. Clemmens; T. Strelkoff; K. Solomon; R. Bliesner; L. Hardy； T. Howell and D. Eisenhauer (1997). Irrigation Performance Measures: Efficiency and Uniformity. J. Irrig. Drain Eng., 123:(6) 423-442.

Eid, A. R.; B. A. Bakry and M. H. Taha (2013). Effect of pulse drip irrigation and mulching systems on yield, quality traits and irrigation water use efficiency of soybean under sandy soil conditions. Agricultural Sciences. 4(5): 249-261.

Elmaloglou, S. T. and N. Malamos (2006). A methodology for determining the surface and vertical components of the wetting front under a surface point source, with root water uptake and evaporation. Irrigation and drainage, 55(1), 99-111

EImaloglou, S., and E. Diamantopoulos (2007). Wetting front advance patterns and water losses by deep percolation under the root zone as influenced by pulsed drip irrigation. Agricultural water management, 90(1), 160-163

Irmak, S.; L. Odhiambo; W. Kranz and D. Eisenhauer (2011). Irrigation efficiency and uniformity, and crop water use efficiency. University of Nebraska, Lincoln. 
James, L. G. (1988). Principles of farm irrigation systems design. John Wiley and Sons Limited. Page, 277.

Kang, Y. (2000). Effect of operating pressures on microirrigation uniformity. Irrigation Science, 20(1): 23-27.

Karimi, M. and A. Gomrokchi (2011). Yield and water use efficiency of corn planted in one or two rows and applying furrow or drip tape irrigation systems in Ghazvin Province, Iran. Irrigation and Drainage, 60(1): 35-41

Karmeli, D. and G. Peri, (1974). Basic principles of pulse irrigation. Journal of the Irrigation and Drainage Division, 100(3): 309-319.

Karmeli, D. and J. Keller. (1975). Trickle irrigation design. Rain Bird sprinkler manufacturing crop. Glendora, California.

Liu, J.; Q. S. Wei; A. Li; C. Wang; W. T. He, and Y. S. Shi (2011). Experimental study on micro-pressure hydraulic characteristics of drip irrigation emitters with multiple types of channels. In Advanced Materials Research (Vol. 255, pp. 3553-3557).

Malek, K., and R. T. Peters (2010). Wetting pattern models for drip irrigation: new empirical model. Journal of Irrigation and Drainage Engineering, 137(8):530-536.

Martin, F. ; S. Olalla; J.A. Valero and C. Fabeiro Cortés (1994). Growth and yield analysis of soybean (Glycine max (L) Merr.) under different irrigation schedules in Castilla-La Mancha, Spain. European Journal of Agronomy. 3(3):187-196.

Mostaghimi, S. and J. K. Mitchell (1983). Pulsed trickling effects on soil moisture distribution. American water resources association. 19(4):605-612.

Pitts, D. J. (1997). Evaluation of micro irrigation systems. South West Florida Research and Education Center, University of Florida.

Pitts, D. J.; Y. J. Tsai; T. A. Obreza and D. L. Myhre (1991). Flooding and drip irrigation frequency effects on tomatoes in South Florida." Transactions of the ASAE (USA). 
Saied, M.M.; M.M. Ragab, S.M. El-Barbary and M.I. El-Shawy (2008) Effect of pressurized irrigation system on soybean and flax yields and some water relations in old lands. Miser J. of Agric. Eng., 25 (1): 87-101.

Schwartzman, M., and B. Zur, (1986). "Emitter spacing and geometry of wetted soil volume.” J. Irrig. Drain. Eng., 112, 242-253.

Shamsi, K. and S. Kobraee (2009). Effect of plant density on the growth, yield and yield components of three soybean varieties under climatic condition of Kermanshah, Iran. J. of Animal and plant Sci. 2 (2): 96 - 99.

Singh, D. K.; T. B. S. Rajput; H. S. Sikarwar; R. N. Sahoo and T. Ahmad (2006). Simulation of soil wetting pattern with subsurface drip irrigation from line source. Agricultural water management, 83(1), 130-134.

Singh, R. ; K. Singh and D. M bhandarkar(2014). Estimation of water requirement for soybean (Glycine max) and wheat (Triticum aestivum) under vertisols of Madhya Pradesh. The Indian Journal of Agricultural Sciences. 84: (2).191-197.

Skaggs, T. H.; T. J., Trout and Y. Rothfuss (2010). Drip irrigation water distribution patterns: effects of emitter rate, pulsing, and antecedent water. Soil Science Society of America Journal. 74(6): 1886-1896.

Wang,D.; M.C.Shannon, C.M.Grieve and S.R. Yates (2000) Soil water and temperature regimes in drip and sprinkler irrigation, and implications to soybean emergence. Agricultural Water Management. 43(2000):15-28.

Zin El-Abedin, T. Z. (2006). Effect of pulse drip irrigation on soil moisture distribution and maize production in clay soil. The 14th. Annual Conference of the Misr Society of Ag. Eng., 22 Nov: 10581076.

Zur, B. (1996). Wetted soil volume as a design objective in trickle irrigation. Irrigation Science, 16(3), 101-105. 


\section{الملخص العربي}

\section{تأثير انماط مختلفة لأنظمة الري على انتاجية محصول فول الصويا تحت ظروف التربة الطينية التئية}

*د. عبدالعزيز محمد عكاشة، **د. وائل فتحي المتولي، ** د. طارق محمود عطافي

تعتبر المياه من أكثر الموارد اهمية لتحقيق التتمية المستدامة في قطاع الإنتاج الزراعي مما ينعكس على اختيار نظام الري المناسب للحصول على انتاجية عالية ومواجهة العجز في موارد المئل المياه

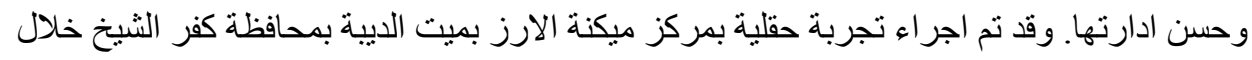

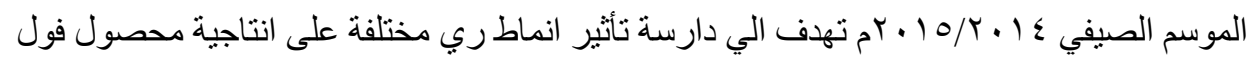
الصويا ورفع كفاءة استخدام مباه الري. الرياه

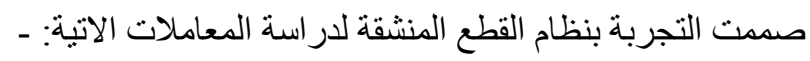

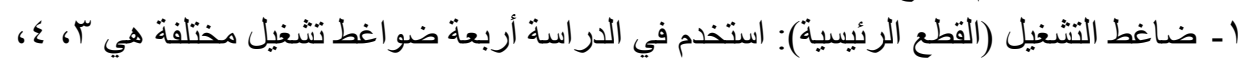
. ץ- معاملات الري (القطع تحت الرئيسية) تم استخدام ثلاثة معاملات للري بالتنقيط السطحي هي

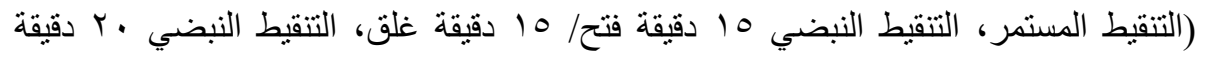
فتح/·r دقيقة غلق) بالإضافة للري السطحي بالخطوط كمعاملة مقارنة.

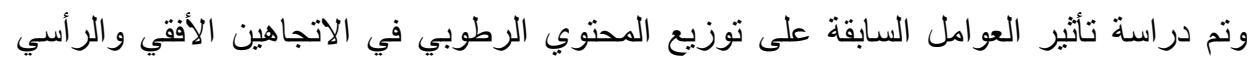
وكفاءات توزيع المياه وكذللك على الإنتاجية وبعض المؤشرات النباتية للمحصول ولئ وكانت أهم النتائج المتحصل عليها كما يلي: • استخدام الري بالتنقيط النبضي يحقق توزيع جيد للرطوبة الأرضية في الاتجاهين الأفقي و الر أسي للتربة الطينية.

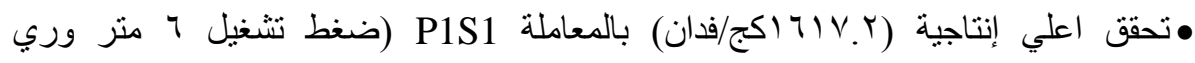

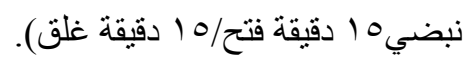

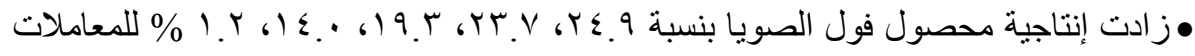
ع2S2 ، P2S1، P1C،P1S2 ،P1S1

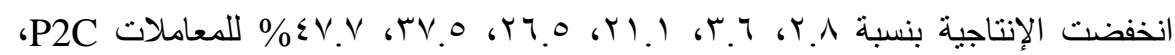
P4C ، P4S2، P4S1،P3C ،P3S2 ،P3S1

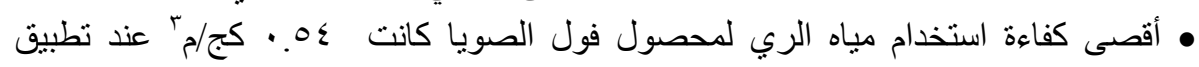

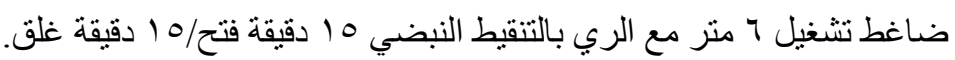

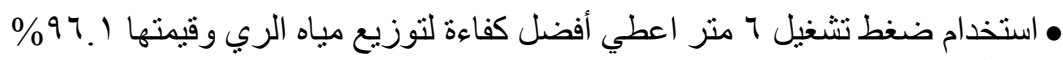

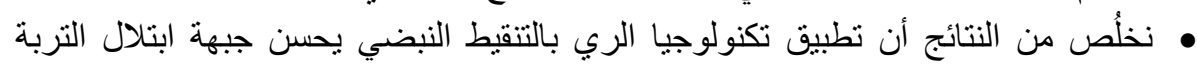

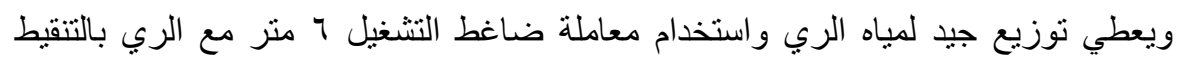
النبضي 10 دقيقة فتح /0 10 دقيقة غلق اعطت أفضل النتائج تحت ظروف التجربة.

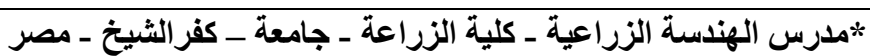

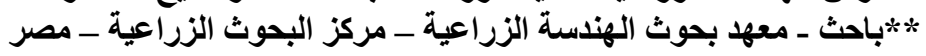

